\title{
JERZY CZEMBOR
}

\section{ALEKSANDRA PIETRUSIŃSKA}

\section{KINGA SMOLIŃSKA}

Instytut Hodowli i Aklimatyzacji Roślin — Państwowy Instytut Badawczy, Radzików

Kierownik Tematu: prof. dr hab. Jerzy Czembor Instytut Hodowli i Aklimatyzacji Roślin - Państwowy

Instytut Badawczy, Radzików, 05-870 Błonie, tel. 22 883273863, e-mail: j.h.czembor@ihar.edu.pl

Prace zostaly wykonane $w$ ramach badań podstawowych na rzecz postępu biologicznego w produkcji roślinnej na podstawie decyzji Ministra Rolnictwa $i$ Rozwoju Wsi nr HOR.hn.802.19.2018, Zadanie nr 27.

\section{Współdziałanie odporności na mączniaka (Blumeria graminis f.sp. hordei) warunkowanej genem mlo z wartością cech gospodarczych jęczmienia ozimego}

\section{Interaction between powdery mildew (Blumeria graminis f.sp. hordei) resistance determined by mlo gene and economical value characteristics in winter barley}

Słowa kluczowe: Blumeria graminis f.sp. hordei, gen mlo, jęczmień ozimy, mączniak prawdziwy

Straty w plonie jęczmienia jarego i ozimego powodowane przez mączniaka prawdziwego sięgają 30\%. Recesywny gen mlo warunkuje odporność form jarych na wszystkie znane dotychczas patotypy Blumeria graminis f.sp. hordei, sprawcy mączniaka prawdziwego (Czembor $i$ in., 2016). Brak jest komercyjnych odmian jęczmienia ozimego, których odporność na mączniaka prawdziwego jest warunkowana tym genem. Do badań wykorzystano linie jęczmienia ozimego: 6-rzędowa BKH 5735 oraz 2-rzędowa: RAH 22, jako donory odporności na mączniaka warunkowanej genem mlo pochodzącym z form jarych. Jako biorców genu mlo wykorzystano dwie 2-rzędowe i dwie 6-rzędowe elitarne odmiany jęczmienia ozimego zarejestrowane w Polsce, o wysokiej wartości cech gospodarczych, lecz podatne na patotypy mączniaka prawdziwego wirulentne w stosunku do genów Ml St, 1-B-53 i innych genów obecnych w nowszych odmianach jęczmienia jarego i ozimego.

Cele szczegółowe realizowane $\mathrm{w}$ roku 2018 to: (1) ocena linii pokolenia $\mathrm{F}_{5} \mathrm{BC}_{2}$ homozygotycznych dla genu mlo oraz wybór i rozmnożenie do dalszych badań sublinii $\mathrm{F}_{6} \mathrm{BC}_{2}$ na podstawie ocen ważnych pod względem gospodarczym cech, $\mathrm{w}$ tym odporności 
na choroby i potencjału plonowania, (2) ocena plonowania i odporności na ważne choroby linii $\mathrm{F}_{5} \mathrm{BC}_{2}$ wybranych na podstawie oceny pod kątem odporności na choroby oraz o korzystnych cechach gospodarczych w warunkach polowych (3) określenie obecności genu mlo dla 1000 roślin $\mathrm{F}_{6} \mathrm{BC}_{2}$, reprezentujących 100-150 linii wytypowanych do badań i reselekcji w warunkach polowych, na podstawie oceny fenotypowej w warunkach kontrolowanych i molekularnej.

W warunkach polowych oceniono wielośrodowiskowo 200 linii wyprowadzonych z siewek pojedynczych roślin należących do 4 populacji mieszańcowych o genotypie mlomlo pokolenia $\mathrm{F}_{5} \mathrm{BC}_{2}$ jęczmienia ozimego (po około 50 linii na populację). Homozygotyczność genotypu mlomlo określona została testem fitopatologicznym i markerami molekularnymi w roku poprzednim. W okresie wegetacji wykonane zostały oceny cech: stan roślin przed zimą, stan po zimie, odporność na choroby, wczesność i wysokość (zgodnie z metodyką COBORU). Nie stwierdzono dużego nasilenia mączniaka prawdziwego, a odporność wszystkich 200 linii i 4 form rodzicielskich oceniono w zakresie 7-9. Znacznie większe zróżnicowanie stwierdzono dla rdzy karłowej. W obrębie populacji (Souleyka $\times$ BKH 735) $\times$ Souleyka oraz (Linia $42 \times$ Metaxa) $\times$ Metaxa można było wydzielić kilka obiektów, których porażenie w Wiatrowie i Szelejewie oceniono na 4 (średni stopień porażenia dla tych populacji wahał się w zakresie 6,1-6,5). Linie należące do populacji (Titus $\times$ BKH 735) $\times$ Titus były w mniejszym stopniu porażone rdzą karłową w stosunku do pozostałych populacji (średnia powyżej 7,0 we wszystkich lokalizacjach). Natomiast były one bardziej podatne na rynchosporiozę (zakres ocen 3,0-9,0; średnie porażenie w zależności od lokalizacji 6,7-7,8). W żadnej z lokalizacji nie stwierdzono dużego nasilenia żółtej karłowatości jęczmienia.

Dodatkowo, w warunkach polowych oceniono 490 siewek należących do 4 populacji mieszańcowych pokoleń $\mathrm{F}_{5} \mathrm{BC}_{2}$ jęczmienia ozimego $\mathrm{w}$ genomie, których $\mathrm{w}$ roku poprzednim potwierdzono fenotypowo i molekularnie obecność genu mlo a 200 z nich wytypowano do dalszych badań wielośrodowiskowych i rozmnożono (po ok. 50 na populację).

Do doświadczeń poletkowych prowadzonych jedno środowiskowo, których celem była ocena plonowania $\mathrm{i}$ odporności na ważne choroby, włączono 35 linii $\mathrm{F}_{5} \mathrm{BC}_{2}$ jęczmienia ozimego, o genomie mlomlo. Układ doświadczeń: doświadczenie 4-powtórzeniowe; poletka $10 \mathrm{~m}^{2}$ do zbioru. W okresie wegetacji wykonano oceny (wg metodyki COBORU): stan roślin przed zimą i po zimie, porażenie przez choroby: mączniak prawdziwy, rdza karłowa, żółta karłowatość jęczmienia, rynchosporioza oraz termin kłoszenia, wysokość roślin i plon. $\mathrm{Na}$ podstawie analiz statystycznych wykonanych za pomocą programu ADOWBLOK-(TP) wykazano istotne zróżnicowanie pomiędzy badanymi liniami w obrębie każdej populacji, oraz wskazano linie plonujące powyżej odmian wzorcowych i wytypowano je do dalszych badań wielośrodowiskowych. Łącznie wytypowano 9 linii 6-rzędowych i 7 2-rzędowych.

Do badań prowadzonych $\mathrm{w}$ warunkach kontrolowanych, mających na celu reselekcję pokolenia $\mathrm{F}_{6} \mathrm{BC}_{2}$ pod katem obecności genu włączono 1000 roślin $\mathrm{F}_{6} \mathrm{BC}_{2}$. W stadium pierwszego liści rośliny zostały zakażone izolatem Bgh 27 i po 8 dniach ocenione w pod 
względem reakcji na infekcję w skali: 0(4)-4, gdzie 0(4) oznacza odporność typu Mlo i 4 - podatność. Próbki drugiego liścia zostały wykorzystane do analiz molekularnych, które prowadzono z wykorzystaniem dwóch markerów HVMlo1 oraz HVMlo3. Marker HVMlo1 okazał się mniej efektywny ponieważ często nie wykazywał polimorfizmu. Jednak analizy prowadzone $\mathrm{z}$ wykorzystaniem tego markera pozwoliły również wskazać genotypy z genem mlo, które na podstawie analiz prowadzonych $\mathrm{z}$ wykorzystaniem markera HVMlo3 włączono do grupy roślin o niezidentyfikowanym profilu lub do grupy roślin o profilu heterogenicznym. Testy fitopatologiczne również potwierdzały jego obecność.

Liczba obiektów wytypowanych do dalszych badań na podstawie wyników testu fitopatologicznego i analiz molekularnych to: formy sześciorzędowe (Souleyka $\times$ BKH 735) $\times$ Souleyka -194 linii; Titus $\times$ BKH 735) $\times$ Titus -185 linii, formy dwurzędowe $($ Linia $42 \times$ SU Vireni) $\times$ SU Virerni -207 linii, (Linia $42 \times$ Metaxa) $\times$ Metaxa 250 linii. Zostaną ocenione pod względem odporności na choroby w warunkach polowych, a 200 rozmnożone w kolejnym roku badań. Prowadzenie równoczesnej selekcji metodami molekularnymi i na podstawie testów fitopatologicznych w obrębie populacji mieszańcowych zwiększa skuteczność trafnego wyboru roślin homozygotycznych o odporności typu Mlo (Czembor i in., 2016). Linie, które zostały wytypowane do dalszych badań na podstawie ocen odporności na ważne gospodarczo choroby oraz plonowania nasiennego ocenione na poziomie odmian wzorcowych lub być włączone również do programów hodowlanych.

\section{LITERATURA}

Czembor J. H., Czembor P. Cz., Doraczyńska O., Pietrusińska A., Radecka-Janusik M. 2016. Wprowadzenie genu mlo do genomu jęczmienia ozimego. Progress in Plant Protection 56 (3): 379 - 387.

Czembor J. H., Pietrusińska A., Czembor H. 2016. Odporność na mączniaka prawdziwego zbóż i traw (Blumeria graminis f.sp. hordei) odmian jęczmienia włączonych do badań rejestrowych w Polsce w roku 2013. Biul. IHAR 280: $3-12$. 
